\title{
Electrochemical Oxidation and Sensing of Methylamine Gas in Room Temperature Ionic Liquids
}

\author{
Krishnan Murugappan, Colin Kang, Debbie S. Silvester*
}

Nanochemistry Research Institute, Department of Chemistry, Curtin University, GPO Box U1987, Perth, 6845, Australia. *Email:d.silvester-dean@curtin.edu.au, Phone: $+61(8) 92667148$

\begin{abstract}
The electrochemical behaviour of methylamine gas in several room temperature ionic liquids (RTILs), $\left[\mathrm{C}_{2} \mathrm{mim}\right]\left[\mathrm{NTf}_{2}\right],\left[\mathrm{C}_{4} \mathrm{mim}\right]\left[\mathrm{NTf}_{2}\right],\left[\mathrm{C}_{6} \mathrm{mim}\right][\mathrm{FAP}],\left[\mathrm{C}_{4} \mathrm{mpyrr}\right]\left[\mathrm{NTf}_{2}\right],\left[\mathrm{C}_{4} \mathrm{mim}\right]\left[\mathrm{BF}_{4}\right]$, and $\left[\mathrm{C}_{4} \mathrm{mim}\right]\left[\mathrm{PF}_{6}\right]$ has been investigated on a Pt microelectrode using cyclic voltammetry. A broad oxidation wave at approximately $3 \mathrm{~V}$, two reduction peaks and another oxidation peak was observed. A complicated mechanism is predicted based on the voltammetry obtained, with ammonia gas as a likely by-product. The currents obtained suggest that methylamine has a high solubility in RTILs, which is important for gas sensing applications. The analytical utility of methylamine was then studied in $\left[\mathrm{C}_{4} \mathrm{mpyrr}\right]\left[\mathrm{NTf}_{2}\right]$ and $\left[\mathrm{C}_{2} \mathrm{mim}\right]\left[\mathrm{NTf}_{2}\right]$. A linear calibration graph with an $\mathrm{R}^{2}$ value of 0.99 and limits of detection of 33 and 34 ppm were obtained respectively, suggesting that RTILs are favourable non-volatile solvents for the electrochemical detection of highly toxic methylamine gas.
\end{abstract}

Keywords: Methylamine oxidation • Room temperature ionic liquids • Cyclic Voltammetry • Electrochemistry $\bullet$ Gas sensing $\bullet$ Reaction mechanism. 


\section{Introduction}

Room temperature ionic liquids (RTILs) are a relatively new class of solvent that are increasingly being investigated for their use in amperometric gas sensing. ${ }^{1-8}$ RTILs are composed entirely of ions and exist in the liquid state at room temperature. ${ }^{9}$ Properties such as low volatility, high thermal stability, wide electrochemical potential window and good intrinsic conductivity make them attractive for use as electrochemical solvents. ${ }^{10}$ It is essential to be able to detect and monitor gases in the area of environmental pollution and occupational health. Many redox-active gases can be detected using amperometric techniques, but the lifetime of an amperometric gas sensor depends on the lifetime of the electrolyte used. Conventional solvents are not able to last in high temperatures and pressures due to the solvent drying out or degrading due to thermal instability. RTILs are not restricted by these issues, due to properties such as negligible vapour pressure and high thermal stability. ${ }^{3}$ These properties also allow stable and robust gas sensors to be made. However before RTILs can be employed in amperometric gas sensors the electrochemical behaviour of the target gases has to be fully understood.

Methylamine is a colourless, toxic and flammable gas at room temperature with a distinct fish or ammonia like odour at concentrations of $100 \mathrm{ppm}$ and above. ${ }^{11}$ It is used to make a wide range of agricultural chemicals such as insecticides and herbicides and used extensively in the production of catalysts, fuel additives, personal care materials and pharmaceuticals. It is also the prime ingredient in mono methylammonium nitrate which is used as a water gel explosive ${ }^{12}$ in the mining industry. Methylamine is also required for the formation of alkanolamines such as methyldiethanolamine (MDEA) and monomethylethanolamine (MMEA) which are essential for gas and oil treatment as they are used for the purification of natural gas. ${ }^{13,14}$ It is also used in the reductive amination of phenyl-2-propanone to produce methamphetamine which is an illegal substance found in 
clandestine laboratories. Furthermore, the need for detection arises as methylamine is a possible tracer for liver or renal diseases. ${ }^{15}$ The current occupational safety and health administration permissible exposure limit (OSHA PEL) is $10 \mathrm{ppm}$ in the gas phase. Given its high toxicity, it is therefore essential to be able to monitor and detect low concentrations of methylamine.

There has been some work on the fundamental behaviour of methylamine in waterbased solvents. For example, Aldaz et al. ${ }^{16}$ reported the electrochemical oxidation of liquid methylamine in an acidic medium on Pt single crystal electrodes and suggested that adsorbed cyanide layers are formed, followed by either carbon monoxide or nitrogen oxide depending on the polarizing potential. Luczak ${ }^{17}$ reported the oxidation of methylamine in an alkaline medium on a gold electrode and found that methylamine is only oxidised in the potential range of gold oxide layer formation. A reaction pathway was proposed, where the amine in solution is adsorbed and then undergoes an oxidation reaction to form an aldehyde and ammonia gas.

Methylamine (in the liquid form) has also been studied in aprotic solvents. Barnes and Mann et al. ${ }^{18}$ reported the electrochemical oxidation of methylamine in acetonitrile on a platinum electrode and proposed two competing mechanisms, one at low potentials and one at high potentials. At low potentials they suggested a one-electron oxidation to form a cation radical, which decomposes to form a carbonium ion and an amidogen radical. At higher potentials methylamine is believed to be oxidised by two electrons to form an iminium salt which hydrolyzes to form aldehyde and ammonia. However all of these experiments were performed using liquid methylamine and there are no obvious reports of the behaviour and sensing of methylamine in the gaseous form. In this work, for the first time we have studied the electrochemical oxidation of methylamine gas in room temperature ionic liquids as electrochemical solvents. 


\section{Experimental Section}

\subsection{Chemical Reagents}

The RTILs 1-ethyl-3-methylimidazolium bis(trifluoromethylsulfonyl)imide $\left(\left[\mathrm{C}_{2} \mathrm{mim}\right]\left[\mathrm{NTf}_{2}\right]\right)$, 1-butyl-3-methylimidazolium bis(trifluoromethylsulfonyl)imide $\left(\left[\mathrm{C}_{4} \mathrm{mim}\right]\left[\mathrm{NTf}_{2}\right]\right)$ and $\mathrm{N}$ butyl- $N$-methylpyrrolidinium bis(trifluoromethylsulfonyl)imide $\quad\left(\left[\mathrm{C}_{4}\right.\right.$ mpyrr $\left.]\left[\mathrm{NTf}_{2}\right]\right)$ were synthesized according to standard literature procedures ${ }^{19,20}$ and kindly donated by the group of Professor Christopher Hardacre at Queens University, Belfast. The RTILs 1-hexyl-3methylimidazolium trifluorotris(pentafluoroethyl)phosphate $\left(\left[\mathrm{C}_{6} \mathrm{mim}\right][\mathrm{FAP}]\right)$, 1-butyl-3methylimidazolium hexafluorophosphate $\left(\left[\mathrm{C}_{4} \mathrm{mim}\right]\left[\mathrm{PF}_{6}\right]\right)$ and 1-butyl-3-methylimidazolium tetrafluroborate $\left(\left[\mathrm{C}_{4} \mathrm{mim}\right]\left[\mathrm{BF}_{4}\right]\right)$ were purchased from Merck KGaA (Kilsyth, Victoria, Australia) at ultra-high purity electrochemical grade (halide content less than $100 \mathrm{ppm}$ ). All RTILs were used as received. Ultra pure water with a resistance of $18.2 \mathrm{M} \Omega \mathrm{cm}$ prepared by an ultra pure laboratory water purification system (Millipore Pty Ltd., North Ryde, NSW, Australia) and acetonitrile (MeCN, Sigma-Aldrich, 99.8\%) were used for washing the electrodes before and after use with RTILs. Methylamine gas (1.3\% or $0.2 \%$, nitrogen fill) was purchased from CAC gases (Auburn, NSW, Australia). High purity nitrogen gas (99.99\%) was purchased from BOC gases (North Ryde, NSW, Australia) and used as a carrier gas. Ferrocene $\left(\mathrm{Fe}\left(\mathrm{C}_{5} \mathrm{H}_{5}\right)_{2}, 98 \%\right.$ purity $)$ and tetra- $N$-butylammonium perchlorate (TBAP, $98 \%$ purity) were purchased from Sigma Aldrich. Methylammonium chloride $\left(\mathrm{CH}_{3} \mathrm{NH}_{3} \mathrm{Cl}\right.$, for synthesis) was purchased from Merck Pty. Ltd., Australia (Kilsyth, Victoria).

\subsection{Electrochemical Experiments}

All electrochemical experiments were performed using a PGSTAT101 Autolab potentiostat (Eco Chemie, Netherlands) interfaced to a PC with NOVA software. A conventional two- 
electrode arrangement was employed, with either a home-made platinum microelectrode (8.3 $\mu \mathrm{m}$ radius $)$ or a home-made gold microelectrode $(10.9 \mu \mathrm{m}$ radius $)$ as the working electrode and a $0.5 \mathrm{~mm}$ diameter silver wire (Sigma Aldrich) as the quasi-reference electrode. The microelectrode was polished on soft lapping pads (Buehler, Illinois) with alumina powder of decreasing size (3, 1 and $0.5 \mu \mathrm{m}$, Kemet, NSW, Australia) before electrochemical experiments. The electrode diameter was calibrated electrochemically by using a well-known redox couple, ferrocene. The steady-state voltammetry of a $2 \mathrm{mM}$ ferrocene (diffusion coefficient $2.3 \times 10^{-5} \mathrm{~cm}^{2} \mathrm{~s}^{-1}$ at $\left.298 \mathrm{~K}\right)^{21}$ solution in acetonitrile with $0.1 \mathrm{M}$ TBAP as the electrolyte was analysed. The electrodes were housed in a glass "T-cell"1 designed for studying microlitre quantities $(20 \mu \mathrm{L})$ of ionic liquids in a controlled environment, previously used to study ammonia ${ }^{4}$ and oxygen gas. ${ }^{5}$ Before the introduction of gas, the cell was purged under high vacuum (Edwards high vacuum pump, Model ES 50) to remove any impurities in the ionic liquid (e.g. dissolved water from atmospheric moisture). When a clean blank signal was obtained, methylamine gas was allowed to flow into the T-cell. The gas was then allowed to partition into the ionic liquid until equilibrium was obtained (typically after 80 min). Experiments were carried out at a temperature of 293( \pm 1$) \mathrm{K}$. An outlet gas line made of PTFE tubing led from the other arm of the "T-cell" into the top of the fume hood. All experiments were carried out inside an aluminium Faraday cage contained inside a fume cupboard. Chronoamperometric transients were achieved using a sample time of $0.01 \mathrm{~s}$. After equilibration, the potential was stepped up from a position of zero current to a potential after the oxidation peak was observed and the current was measured for $10 \mathrm{~s}$. A fit using the Shoup and Szabo equation ${ }^{22}$ was performed using the software package Origin 6.0 (Microcal Software Inc.) after deletion of the first 2 points to obtain the diffusion coefficient $(D)$ and the number of electrons multiplied by concentration $(n c)$. 


\subsection{Gas mixing setup}

A similar gas mixing setup that was reported by Lee et al. ${ }^{23}$ was used to obtain different concentrations of methylamine. The \% (or ppm) concentration of methylamine that was introduced into the T-cell was calculated using the relative flow rates of the two flow meters. A digital flowmeter (0-1.2 L/min, John Morris Scientific, NSW, Australia) was used for the nitrogen gas and an analogue flowmeter $\left(0-60 \mathrm{~cm}^{3} / \mathrm{min}\right.$, Dwyer, NSW, Australia) was used for the methylamine gas. It took approximately 80 minutes for saturation to occur in the most viscous ionic liquids and the time taken between each concentration change was 45 minutes.

\section{Results and Discussion}

The electrochemistry of methylamine has been investigated in six different RTILs, $\left[\mathrm{C}_{2} \mathrm{mim}\right]\left[\mathrm{NTf}_{2}\right], \quad\left[\mathrm{C}_{4} \mathrm{mim}\right]\left[\mathrm{NTf}_{2}\right], \quad\left[\mathrm{C}_{6} \mathrm{mim}\right][\mathrm{FAP}] \quad\left[\mathrm{C}_{4} \mathrm{mpyrr}\right]\left[\mathrm{NTf}_{2}\right], \quad\left[\mathrm{C}_{4} \mathrm{mim}\right]\left[\mathrm{BF}_{4}\right]$, and $\left[\mathrm{C}_{4} \mathrm{mim}\right]\left[\mathrm{PF}_{6}\right]$ on a $\mathrm{Pt}$ microelectrode. Experiments were also performed on a $\mathrm{Au}$ micro electrode in $\left[\mathrm{C}_{4}\right.$ mpyrr $]\left[\mathrm{NTf}_{2}\right]$, (see supporting information, figure $\mathrm{S} 1$ ). However the presence of additional processes in the voltammetry on the Au surface, which could be due to water impurities or the formation of gold oxides, resulted in all further experiments being conducted only on the Pt surface, as described below. All efforts were made to remove water from the RTIL by vacuum techniques before the introduction of gas (see experimental section), but it is possible that trace water may be present ${ }^{24}$. However, the amount of water is not believed to be sufficient to interfere with the reaction mechanism on Pt surfaces (see discussion below), which are believed to be less sensitive to trace water compared to Au. 


\subsection{Electrochemical Response of $1.3 \%$ Methylamine Gas in $\left[\mathrm{C}_{4} \mathrm{mpyrr}\right]\left[\mathrm{NTf}_{2}\right]$ on a Pt Microelectrode.}

Figure 1 shows typical cyclic voltammetry $(\mathrm{CV})$ of $1.3 \%$ methylamine (nitrogen fill) in the RTIL $\left[\mathrm{C}_{4}\right.$ mpyrr] $\left[\mathrm{NTf}_{2}\right]$ at a scan rate of $0.1 \mathrm{~V} / \mathrm{s}$ when scanned from $0.2 \mathrm{~V}$ to $3.2 \mathrm{~V}$ to $-1.5 \mathrm{~V}$ and back to $0.2 \mathrm{~V}$. The response in the absence of methylamine is shown as the dotted line. It can be seen that there is a single broad oxidation wave, process $\mathrm{I}$, at approximately $3 \mathrm{~V}$ followed by two reduction peaks at $0.1 \mathrm{~V}$ and $-0.3 \mathrm{~V}$ (peaks II and III). It can also be seen that there is an oxidation feature (peak IV) at $-0.06 \mathrm{~V}$. The absence of peaks II, III and IV when scanned negative first indicates that they are a direct consequence of process $\mathrm{I}$, and likely to be peaks from products formed after methylamine oxidation.

It is also important to point out that the CV looks very similar to that seen of the electrochemical oxidation of ammonia in RTILs where four processes are also present. ${ }^{4}$ The processes for ammonia oxidation were assigned to the following reactions:

Peak (I)

$$
\mathrm{NH}_{3}(\mathrm{~g})+3 \mathrm{~A}^{-} \rightarrow \frac{1}{2} \mathrm{~N}_{2}(\mathrm{~g})+3 \mathrm{HA}+3 \mathrm{e}^{-}
$$

where $\mathrm{A}^{-}$is the anion of the RTIL $\left(\left[\mathrm{NTf}_{2}\right]^{-}\right)$. HA can then transfer its proton to an ammonia molecule in the following equilibrium reaction:

$$
\mathrm{HA}+\mathrm{NH}_{3}(\mathrm{~g}) \rightleftharpoons \mathrm{NH}_{4}^{+}+\mathrm{A}^{-}
$$

Therefore, there are two species that can undergo reduction: the solvated proton, HA, (eq 3) and ammonium ion, $\mathrm{NH}_{4}{ }^{+}$, (eq 4): ${ }^{4}$

Peak (II)

$$
\mathrm{HA}+\mathrm{e}^{-} \rightarrow \mathrm{A}^{-}+\mathrm{H}(\mathrm{ads})
$$

Peak (III)

$$
\mathrm{NH}_{4}^{+}+\mathrm{e}^{-} \rightarrow \mathrm{NH}_{3}(\mathrm{~g})+\mathrm{H}(\mathrm{ads})
$$

In both of these reactions, adsorbed hydrogen/protons are formed on the surface, which are 
then oxidised in peak IV.

In the case of methylamine, the oxidation mechanism is thought to be much more complex. Barnes and Mann ${ }^{18}$ proposed that that the electrochemical oxidation of liquid methylamine produces ammonia gas and other by-products. As ammonia is already at a potential where it can be oxidised, it is instantly oxidised and the current is added to that of the methylamine oxidation current. Therefore we believe that process $\mathrm{I}$ in figure 1 is a result of a combination of methylamine and ammonia oxidation, likely following an overall 5-electron process (see mechanism proposed at high potentials by Barnes and Mann). ${ }^{18}$ It is believed that peaks II and III in the CVs follow the same mechanism as depicted in equations 3 and 4 . To rule out any possibility that peak III could be due to the reduction of the methylammonium ion instead of the ammonium ion, methylammonium chloride was dissolved in $\left[\mathrm{C}_{4}\right.$ mpyrr $]\left[\mathrm{NTf}_{2}\right]$ and scanned negative from $0.4 \mathrm{~V}$ to $-2 \mathrm{~V}$. The absence of any peaks suggests that peaks II and III are not from the reduction of the methylammonium ion. Peak IV for methylamine in Figure 1 is therefore likely to be the oxidation of adsorbed hydrogen as in the case of ammonia.

In order to support the proposed mechanism, experiments were performed with methylamine gas in the presence of ammonia. When both ammonia and methylamine are present, two oxidation waves were observed (see supporting information, S2), with ammonia oxidation occurring prior to methylamine oxidation. This supports the suggestion that any ammonia formed is instantly oxidised at the potential for methylamine oxidation. Importantly, on the reverse scan, the same three peaks are present (II, III and IV) suggesting that it is indeed the reaction products from ammonia oxidation giving rise to the observed voltammetry. 
The reasonably high currents obtained at concentrations of $1.3 \%$ methylamine in the gas phase (nitrogen fill) shows the high solubility of methylamine in $\left[\mathrm{C}_{4}\right.$ mpyrr $]\left[\mathrm{NTf}_{2}\right]$ which is very advantageous for sensing applications and will be explored later in section 3.3

\subsection{Electrochemical Study of Methylamine in Different RTILs.}

In order to investigate the electrochemical behaviour of methylamine in different RTILs, the electrochemical oxidation at a range of scan rates from $0.01 \mathrm{~V} / \mathrm{s}$ to $4 \mathrm{~V} / \mathrm{s}$ was performed in six different RTILs with varying anions and cations, namely, $\left[\mathrm{C}_{2} \mathrm{mim}\right]\left[\mathrm{NTf}_{2}\right]$, $\left[\mathrm{C}_{4} \mathrm{mim}\right]\left[\mathrm{NTf}_{2}\right],\left[\mathrm{C}_{6} \mathrm{mim}\right][\mathrm{FAP}]\left[\mathrm{C}_{4} \mathrm{mpyrr}\right]\left[\mathrm{NTf}_{2}\right],\left[\mathrm{C}_{4} \mathrm{mim}\right]\left[\mathrm{BF}_{4}\right]$, and $\left[\mathrm{C}_{4} \mathrm{mim}\right]\left[\mathrm{PF}_{6}\right]$. Figure 2 shows typical CVs obtained and all are highly reproducible on consecutive days. It can be seen clearly that the voltammograms exhibit a very similar behaviour with the presence of four processes (I to IV) as described in section 3.1. However, the voltammetry in the [FAP] ${ }^{-}$ ionic liquid shows a double wave for the oxidation, suggesting that this RTIL may not be the most suitable for further analytical studies. In all the six RTILs, peak II becomes relatively smaller at higher scan rates which is analagous to that reported for ammonia oxidation in RTILs. $^{4}$

It is noted that the Randles-Sevcik style analysis to determine diffusional mass transport may not be applicable due to the complicated oxidation mechanism of methylamine, possibly giving rise to higher than expected currents due to the formation and instant oxidation of ammonia. However, maximum currents for the oxidative process I for the six RTILs at the various scan rates were plotted against the square root of scan rate and a linear response $\left(R^{2}\right.$ value $=0.99$, see Figure $S 3$ of the supporting information) was obtained for all the RTILs. This, combined with absence of any obvious adsorption processes (return of the blank voltammogram when methylamine is 


\section{replaced by nitrogen), suggests that the electrochemical process occurring is most likely}

diffusion controlled. The peak potential of this wave (process I) becomes more negative as the scan rate is increased which indicates electrochemical irreversibility. ${ }^{25,26}$ It is also possible that the scan rate dependence of peak potential may be due to $i R$ drop, however, the currents passed during experiments are very low as the electrode is a microelectrode, and iR drop is expected to be insignificant.

Chronoamperometric transients were performed on $1.3 \%$ methylamine in the RTILs and an example is shown in Figure 3 for $1.3 \%$ methylamine in $\left[\mathrm{C}_{2} \operatorname{mim}\right]\left[\mathrm{NTf}_{2}\right]$. The experimental data was fitted with the Shoup and Szabo ${ }^{22}$ expression and diffusion coefficients between ca. 1 to $4.5 \times 10^{-10} \mathrm{~m}^{2} \mathrm{~s}^{-1}$ were obtained for the various RTILs which follow approximately the Stokes Einstein relationship where the diffusion coefficient is inversely proportional to solvent viscosity. ${ }^{27}$ It should be noted here that due to the complicated mechanism of the electrochemical oxidation of methylamine, which produces ammonia, the diffusion coefficient reported could be a combination of both ammonia and methylamine. The fitting also gave $n c$ values in all the RTILs between $15-25 \mathrm{mM}$ assuming a five electron process (see Barnes and Mann), ${ }^{18}$ which gives a concentration of approximately 3-5 $\mathrm{mM}$ for $1.3 \%$ methylamine. This suggests that the saturated concentration (100\%) methylamine (assuming a linear increase at higher concentrations) will be approximately $230-400 \mathrm{mM}$ which is relatively high and this is extremely favourable for sensing purposes. This compares to $\sim 2-4$ $\mathrm{mM}$ for oxygen gas, ${ }^{5} \sim 3-10 \mathrm{mM}$ for hydrogen gas, ${ }^{28} \sim 200-1600 \mathrm{mM}$ for sulphur dioxide gas ${ }^{3}$ and $\sim 200-500 \mathrm{mM}$ for hydrogen sulphide gas. ${ }^{7}$

\subsection{Analytical Utility of Methylamine in $\left[\mathrm{C}_{2} \mathrm{mim}\right]\left[\mathrm{NTf}_{2}\right]$ and $\left[\mathrm{C}_{4} \mathrm{mpyrr}\right]\left[\mathrm{NTf}_{2}\right]$.}

Once the fundamental behaviour was understood, the analytical utility of methylamine was studied in two RTILs $\left[\mathrm{C}_{2} \mathrm{mim}\right]\left[\mathrm{NTf}_{2}\right]$ and $\left[\mathrm{C}_{4} \mathrm{mpyrr}\right]\left[\mathrm{NTf}_{2}\right] .\left[\mathrm{C}_{4} \mathrm{mpyrr}\right]\left[\mathrm{NTf}_{2}\right]$ was chosen due 
to all four processes being clearly defined and $\left[\mathrm{C}_{2} \mathrm{mim}\right]\left[\mathrm{NTf}_{2}\right]$ was chosen due to the fastest gas saturation time as it is the least viscous RTIL. Voltammetry was recorded at a scan rate of $0.1 \mathrm{~V} / \mathrm{s}$. Figure 4 shows typical CVs of six different concentrations of methylamine (from 104-1048 ppm) on a Pt microelectrode. On both graphs it can be seen that as the concentration increases, the currents of all four processes (I to IV) increases. The insets to the figures show the corresponding calibration graphs (plots of maximum current for process 1 vs gas phase concentration). It can be seen that for both the ionic liquids a linear behaviour is observed with $\mathrm{R}^{2}$ values of $>0.99$, and sensitivities/gradients of $2.13 \times 10^{-12}$ and $1.24 \times 10^{-12}$ $\mathrm{A} / \mathrm{ppm}$ in $\left[\mathrm{C}_{2} \mathrm{mim}\right]\left[\mathrm{NTf}_{2}\right]$ and $\left[\mathrm{C}_{4} \mathrm{mpyrr}\right]\left[\mathrm{NTf}_{2}\right]$, respectively. Due to the complicated oxidation mechanism, it was originally unclear if the calibration curves would be linear, however, excellent linearity was observed which is very important for sensing applications. Limits of detection (LODs) of 34 and 33 ppm (based on three times the standard deviation of the line of best fit) were obtained for $\left[\mathrm{C}_{2} \mathrm{mim}\right]\left[\mathrm{NTf}_{2}\right]$ and $\left[\mathrm{C}_{4} \mathrm{mpyrr}\right]\left[\mathrm{NTf}_{2}\right]$, respectively, which clearly shows that RTILs can be used as a solvent for the electrochemical detection of low concentrations methylamine. Other techniques such as differential pulse voltammetry and square wave voltammetry could be employed in future work to obtain even lower LODs.

\section{Conclusions}

The electrochemical oxidation of methylamine gas has been studied in various RTILs for the first time. In all the RTILs, similar behaviour is observed where one broad oxidative wave and two reduction peaks are seen, followed by another oxidation peak. The mechanism is believed to be highly complex, involving the formation of ammonia as a by-product which is itself instantly oxidised. A high solubility of several hundred $\mathrm{mM}$ in the RTIL phase is estimated from chronoamperometric fitting. The analytical utility of methylamine was then studied in $\left[\mathrm{C}_{2} \mathrm{mim}\right]\left[\mathrm{NTf}_{2}\right]$ and $\left[\mathrm{C}_{4} \mathrm{mpyrr}\right]\left[\mathrm{NTf}_{2}\right]$ and the calibration graphs obtained were 
linear with LODs of 34 and 33 ppm respectively which suggests that RTILs can be used as a favourable solvent for the electrochemical sensing of methylamine.

\section{Supporting Information}

$\mathrm{CVs}$ for the experiments performed on an $\mathrm{Au}$ microelectrode in $\left[\mathrm{C}_{4} \mathrm{mpyrr}\right]\left[\mathrm{NTf}_{2}\right], \mathrm{CVs}$ for methylamine oxidation in the presence of ammonia on a $\mathrm{Pt}$ microelectrode in $\left[\mathrm{C}_{4}\right.$ mpyrr $]\left[\mathrm{NTf}_{2}\right]$ and a plot of the current obtained for the oxidative process I for the six RTILs vs. the square root of scan rate for the Pt electrode is attached. This material is available free of charge via the Internet at http://pubs.acs.org.

\section{Author Information}

Corresponding Author - E-mail: d.silvester-dean@curtin.edu.au

\section{Author Contributions}

The manuscript was written through contributions of all authors. All authors have given approval to the final version of the manuscript.

\section{Author Contributions}

K.M, C.K and D.S.S contributed equally to this work.

\section{Acknowledgements}

K.M. thanks Curtin University for the award of a Curtin International Postgraduate Research Scholarship and D.S.S. thanks the Australian Research Council for funding via a Discovery Early Career Research Award (DE120101456). 


\section{References}

(1) Silvester, D. S.; Aldous, L.; Hardacre, C.; Compton, R. G. J. Phys. Chem. B 2007, 111, 5000-5007.

(2) Rogers, E. I.; O'Mahony, A. M.; Aldous, L.; Compton, R. G. ECS Trans. 2010, 33, 473502.

(3) Barrosse-Antle, L. E.; Silvester, D. S.; Aldous, L.; Hardacre, C.; Compton, R. G. J. Phys. Chem. C 2008, 112, 3398-3404.

(4) Ji, X.; Silvester, D. S.; Aldous, L.; Hardacre, C.; Compton, R. G. J. Phys. Chem. C 2007, $111,9562-9572$.

(5) Huang, X.-J.; Rogers, E. I.; Hardacre, C.; Compton, R. G. J. Phys. Chem. B 2009, 113, 8953-8959.

(6) Silvester, D. S.; Compton, R. G. Z. Phys. Chem. 2006, 220, 1247-1274.

(7) O'Mahony, A. M.; Silvester, D. S.; Aldous, L.; Hardacre, C.; Compton, R. G. J. Phys. Chem. C 2008, 112, 7725-7730.

(8) Huang, X.-J.; Silvester, D. S.; Streeter, I.; Aldous, L.; Hardacre, C.; Compton, R. G. J. Phys. Chem. C 2008, 112, 19477-19483.

(9) Buzzeo, M. C.; Hardacre, C.; Compton, R. G. Anal. Chem. 2004, 76, 4583-4588.

(10) Silvester, D. S. Analyst 2011, 136, 4871-4882.

(11) Association, C. G. Handbook of Compressed Gases; Springer US, 1999.

(12) Miron, Y. J. Hazard. Mater. 1980, 3, 301-321.

(13) Zhang, K.; Hawrylak, B.; Palepu, R.; Tremaine, P. R. J. Chem. Thermodyn. 2002, 34, 679-710.

(14) Jou, F.-Y.; Otto, F. D.; Mather, A. E. Ind. Eng. Chem. Res. 1994, 33, 2002-2005.

(15) Sigrist, M. W.; Bartlome, R.; Marinov, D.; Rey, J. M.; Vogler, D. E.; Wächter, H. Appl. Phys. B 2008, 90, 289-300.

(16) Huerta, F.; Morallón, E.; Pérez, J. M.; Vázquez, J. L.; Aldaz, A. J. Electroanal. Chem. $1999,469,159-169$.

(17) Łuczak, T. J. Appl. Electrochem. 2007, 37, 461-466.

(18) Barnes, K. K.; Mann, C. K. J. Org. Chem. 1967, 32, 1474-1479.

(19) Bonhôte, P.; Dias, A.-P.; Papageorgiou, N.; Kalyanasundaram, K.; Grätzel, M. Inorg. Chem. 1996, 35, 1168-1178.

(20) MacFarlane, D. R.; Meakin, P.; Sun, J.; Amini, N.; Forsyth, M. J. Phys. Chem. B 1999, $103,4164-4170$.

(21) Sharp, M. Electrochim. Acta 1983, 28, 301-308.

(22) Shoup, D.; Szabo, A. J. Electroanal. Chem. 1982, 140, 237-245.

(23) Lee, J.; Murugappan, K.; Arrigan, D. W. M.; Silvester, D. S. Electrochim. Acta 2013, $101,158-168$.

(24) O'Mahony, A. M.; Silvester, D. S.; Aldous, L.; Hardacre, C.; Compton, R. G. J. Chem. Eng. Data 2008, 53, 2884-2891.

(25) Ji, X.; Banks, C. E.; Silvester, D. S.; Aldous, L.; Hardacre, C.; Compton, R. G. Electroanalysis 2007, 19, 2194-2201.

(26) Compton, R. G.; Banks, C. E. Understanding Voltammetry; World Scientific, 2007.

(27) Barrosse-Antle, L. E.; Bond, A. M.; Compton, R. G.; O'Mahony, A. M.; Rogers, E. I.; Silvester, D. S. Chem. Asian J. 2010, 5, 202-230.

(28) Silvester, D. S.; Ward, K. R.; Aldous, L.; Hardacre, C.; Compton, R. G. J. Electroanal. Chem. 2008, 618, 53-60. 


\section{Figures}

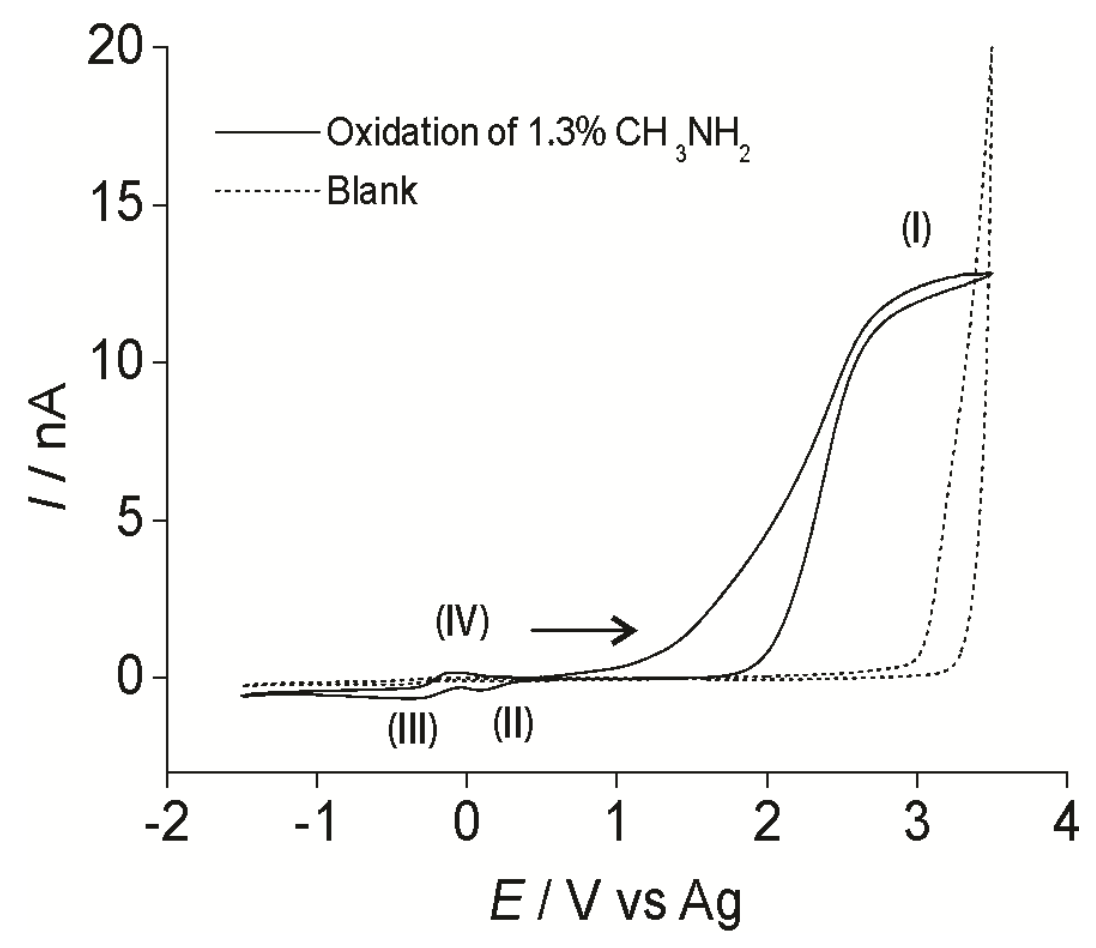

Figure 1: $\mathrm{CV}$ for the oxidation of $1.3 \%$ methylamine gas (nitrogen fill) on a $8.3 \mu \mathrm{m}$ radius $\mathrm{Pt}$ electrode in $\left[\mathrm{C}_{4}\right.$ mpyrr $]\left[\mathrm{NTf}_{2}\right]$ at a scan rate of $0.1 \mathrm{~V} / \mathrm{s}$. Dotted line is the response in the absence of methylamine 


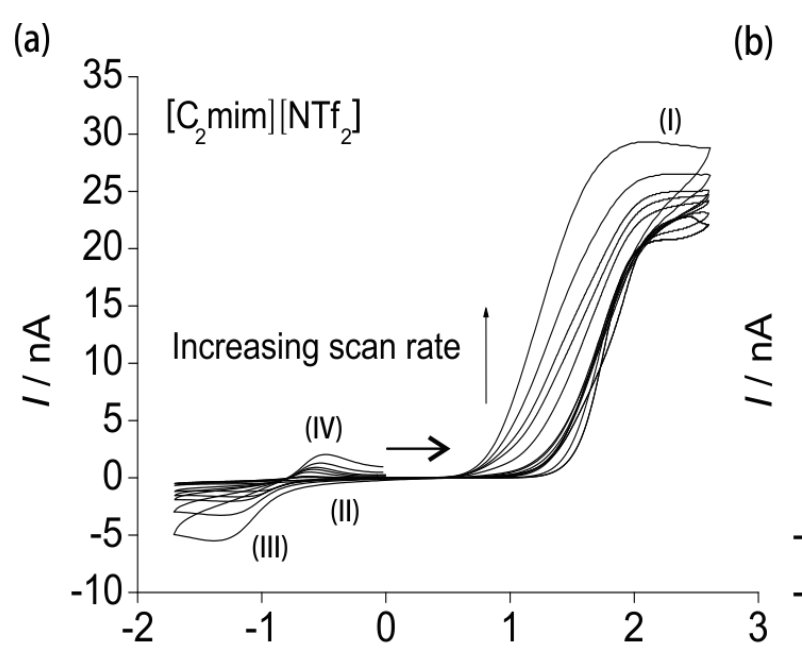

(c)

$E / \mathrm{V}$ vs $\mathrm{Ag}$

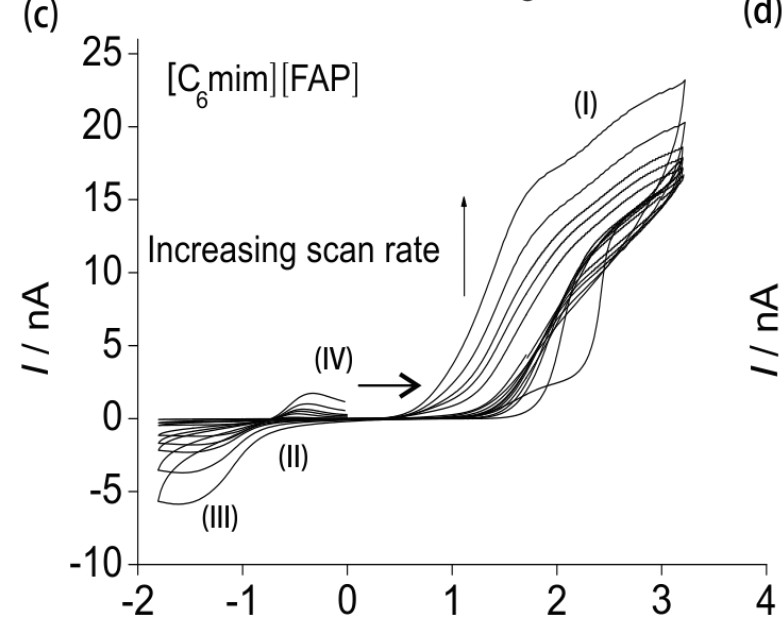

E/ V vs Ag

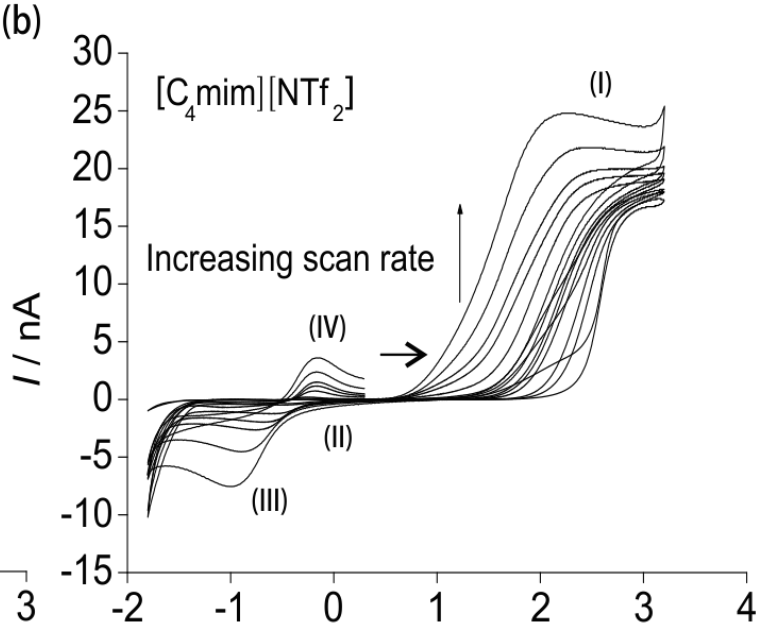

(d)

$E / \mathrm{V}$ v $\mathrm{Ag}$

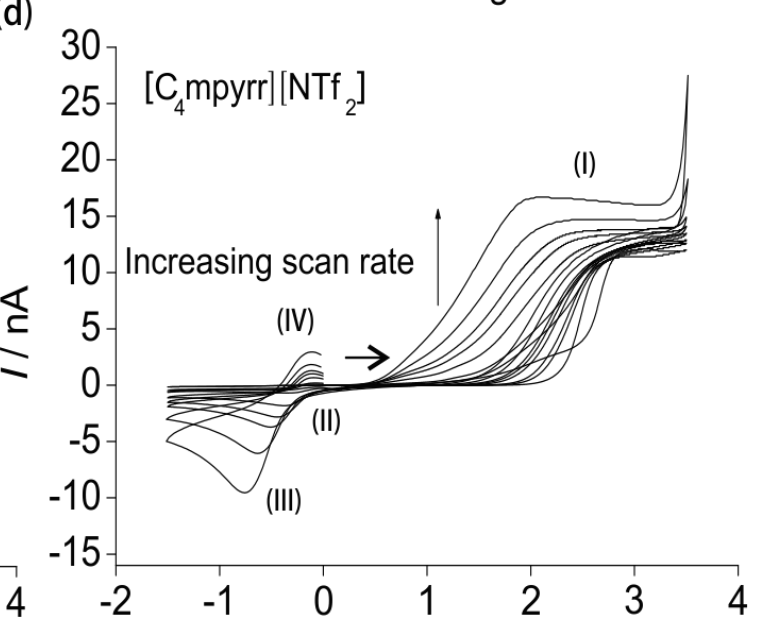

\section{$E / \mathrm{V}$ vs Ag}
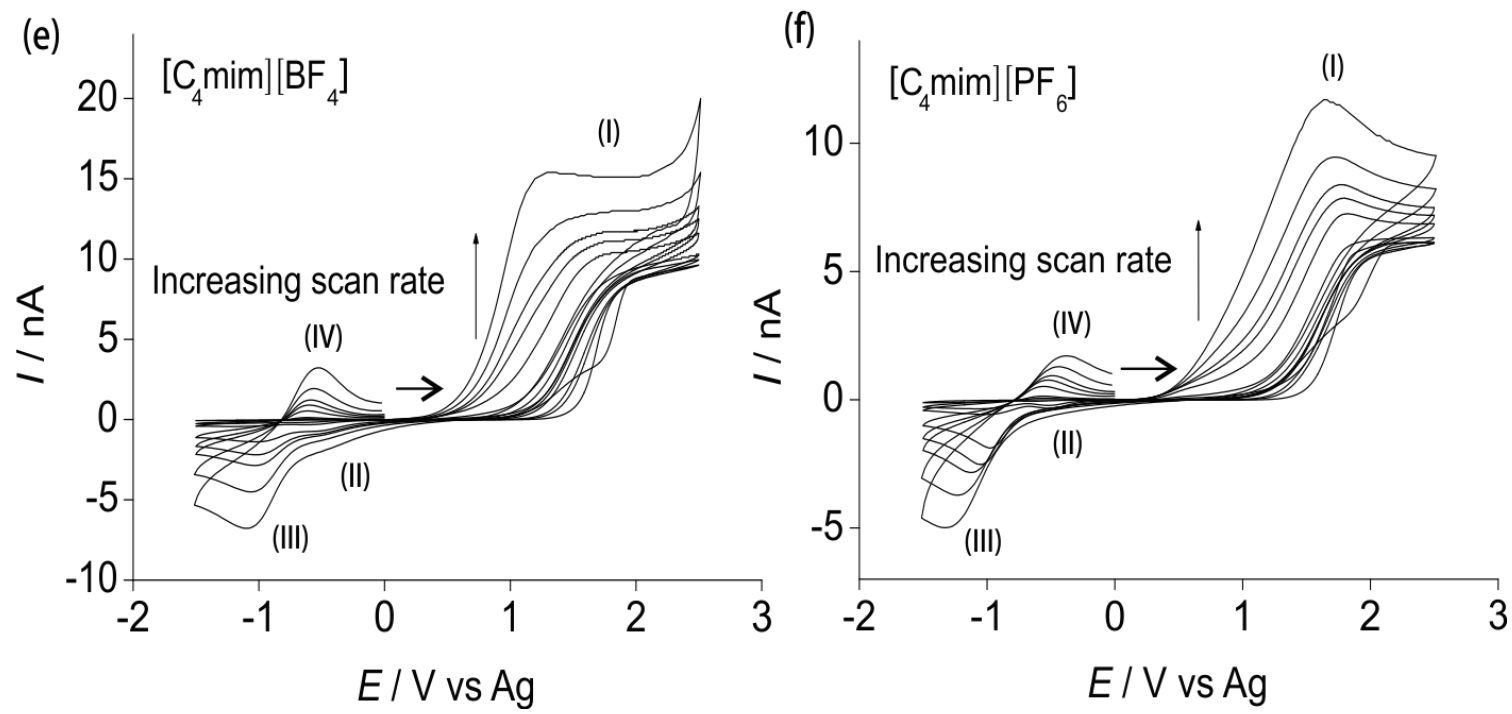

Figure 2: $\mathrm{CV}$ for the oxidation of $1.3 \%$ methylamine gas on a $8.3 \mu \mathrm{m}$ radius $\mathrm{Pt}$ electrode in a) $\left[\mathrm{C}_{2} \mathrm{mim}\right]\left[\mathrm{NTf}_{2}\right], \quad$ b) $\left[\mathrm{C}_{4} \mathrm{mim}\right]\left[\mathrm{NTf}_{2}\right], \quad$ c) $\left[\mathrm{C}_{6} \mathrm{mim}\right][\mathrm{FAP}], \quad$ d) $\left[\mathrm{C}_{4} \mathrm{mpyrr}\right]\left[\mathrm{NTf}_{2}\right], \quad$ e) $\left.\left[\mathrm{C}_{4} \mathrm{mim}\right]\left[\mathrm{BF}_{4}\right], \mathrm{f}\right)\left[\mathrm{C}_{4} \mathrm{mim}\right]\left[\mathrm{PF}_{6}\right]$ at varying scan rates from $0.01 \mathrm{~V} / \mathrm{s}$ to $4 \mathrm{~V} / \mathrm{s}$. 


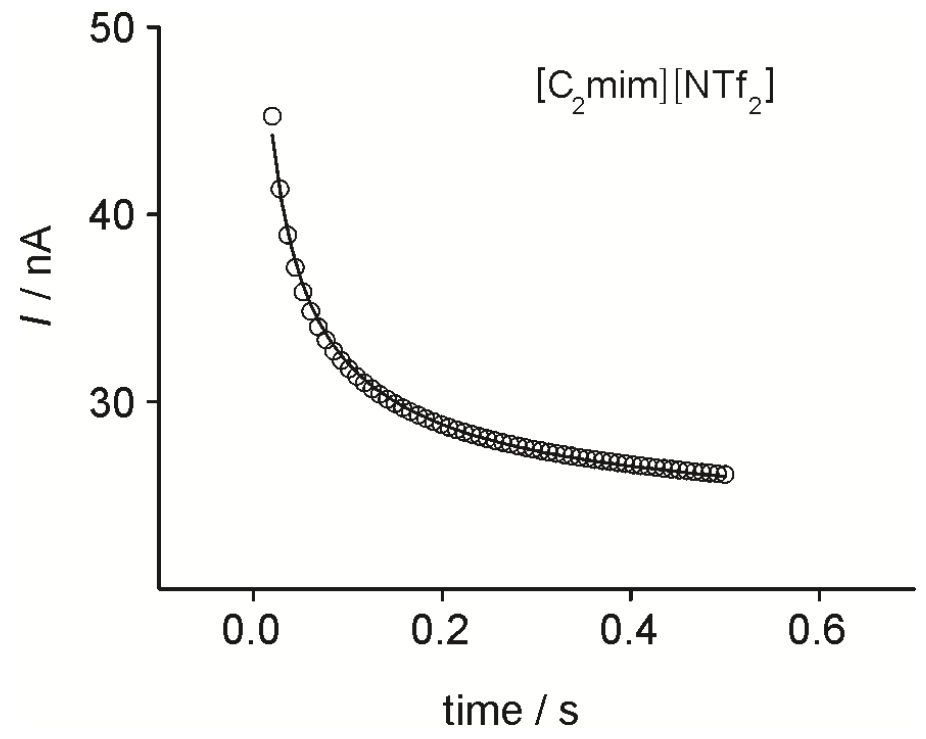

Figure 3: Chronoamperometric transient for the oxidation of $1.3 \%$ methylamine gas in the RTIL $\left[\mathrm{C}_{2} \mathrm{mim}\right]\left[\mathrm{NTf}_{2}\right]$. The potential was stepped from $0 \mathrm{~V}$ to $+2.6 \mathrm{~V}$. Experimental (-) and fitted theoretical (o) data following the Shoup and Szabo expression. ${ }^{22}$ 

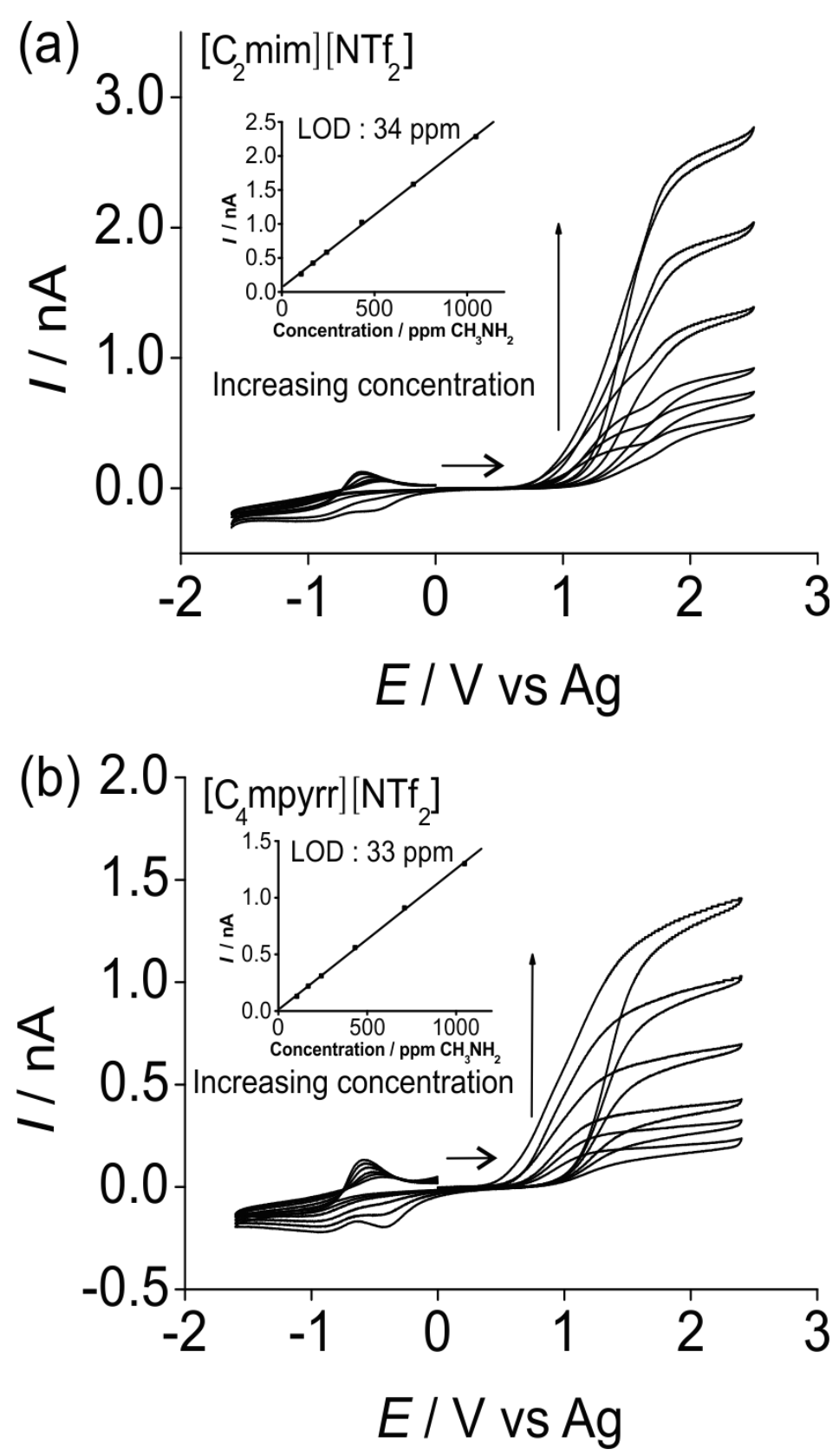

Figure 4: CV for the oxidation of different concentrations (104, 168, 242, 431, 710 and 1048 $\mathrm{ppm}$ ) of methylamine on a $8.3 \mu \mathrm{m}$ radius $\mathrm{Pt}$ electrode in a) $\left[\mathrm{C}_{2} \mathrm{mim}\right]\left[\mathrm{NTf}_{2}\right]$, b) $\left[\mathrm{C}_{4} \mathrm{mpyrr}\right]\left[\mathrm{NTf}_{2}\right]$, at a scan rate $0.1 \mathrm{~V} / \mathrm{s}$. The insets show plots of oxidation current vs concentration. 
Table of Contents Figure

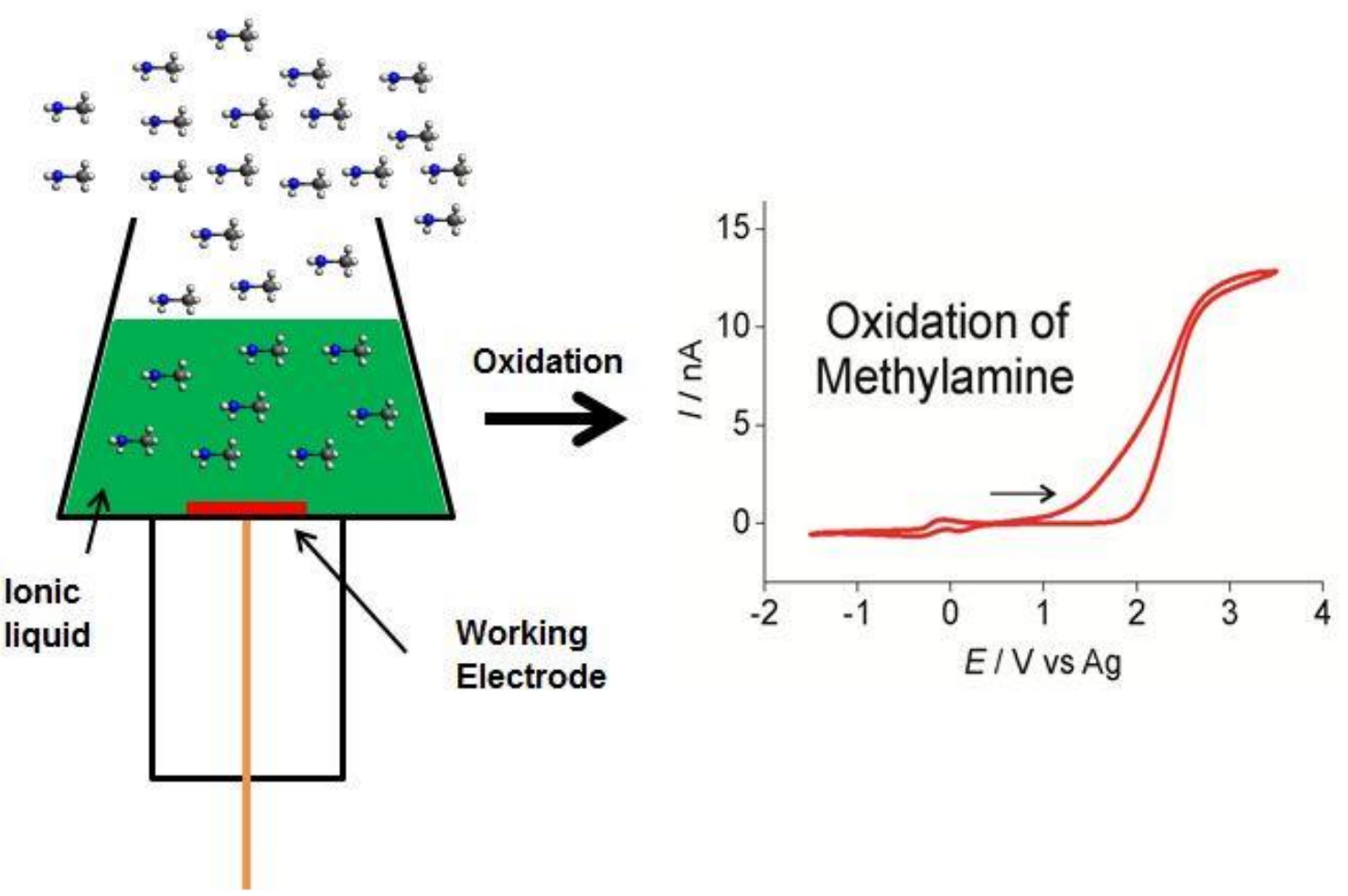

